\title{
Role Playing Pada Perkuliahan Fisika Lingkungan Sub Bahasan Pencemaran
}

\author{
Erwina Oktavianty \\ Pendidikan Fisika, FKIP Universitas Tanjungpura
}

\begin{abstract}
Abstrak
Penelitian ini bertujuan untuk meningkatkan aktivitas mahasiswa pada perkuliahan fisika lingkungan sub bahasan pencemaran. Penelitian yang digunakan adalah action research. Mahasiswa program studi pendidikan Fisika Kerjasama Pemerintah Daerah Kabupaten Ketapang Jurusan P.MIPA FKIP Untan angkatan 2006 yang berjumlah 18 orang berpastisipasi dalam penelitian ini. Teknik pengumpul data berupa pengamatan lapangan, dokumentasi sedangkan alat pengumpul data adalah lembar pengamatan aktivitas mahasiswa. Berdasarkan hasil pengamatan diperoleh peningkatan aktivitas mahasiswa sebesar 7,4\% pada siklus kedua dari siklus pertama pada perkuliahan fisika lingkungan sub bahasan pencemaran tanah, air dan udara.
\end{abstract}

Kata kunci: role playing, fisika lingkungan

\section{Pendahuluan}

Mata kuliah fisika lingkungan adalah salah satu mata kuliah wajib bagi mahasiswa program studi pendidikan fisika. Dimana mata kuliah ini bertujuan untuk membahas dan menyelesaikan permasalahan lingkungan dengan kajian fisika. Salah satu bahasannya adalah pencemaran, yang terdiri dari pencemaran air, tanah, udara dan suara (akustik).

Pada bahasan pencemaran, mahasiswa dituntut dapat mengambil keputusan mengenai akibat yang akan ditanggung oleh mahasiswa dan masyarakat pada umumnya. Sehingga diperlukan pengetahuan yang mendasar dan kemampuan mengambil keputusan secara cepat dan tepat dalam membahas permasalahan lingkungan.

Pencemaran merupakan isu yang strategis dibahas dalam perkuliahan fisika lingkungan karena terkait dengan isu global warming. Sedangkan tujuan pendidikan harus mampu mendukung kompetensi lulusan, yaitu pengetahuan, nilai, sikap, dan kemampuan untuk mendekatkan dirinya dengan lingkungan alam, sosial, budaya, dan kebutuhan daerah. Sementara itu, kondisi pendidikan di negara kita dewasa ini, lebih diwarnai oleh pendekatan yang menitikberatkan pada model belajar konvensional seperti ceramah, sehingga kurang mampu merangsang siswa untuk terlibat aktif dalam proses belajar mengajar (Suwarma, 1991; Jarolimek, 1967). Sedangkan suasana tersebut menjauhkan mahasiswa untuk dapat bermasyarakat dengan baik.

Pola perkuliahan fisika lingkungan program kerja sama pemda ketapang masih bersifat teacher centered. Kecenderungan perkuliahan demikian, mengakibatkan lemahnya pengembangan potensi diri mahasiswa dalam perkuliahan sehingga prestasi belajar yang dicapai tidak optimal. Kesan menonjolnya verbalisme dalam pelaksanaan kegiatan belajar mengajar di kelas masih terlalu kuat.

\section{Role Playing}

Salah satu alternatif metode pembelajaran yang dapat dikembangkan untuk memenuhi tuntutan tersebut adalah metode belajar role playing. Davies (1987) mengemukakan bahwa penggunaan role playing dapat membantu 
siswa dalam mencapai tujuan-tujuan afektif. Esensi role playing, menurut Chesler dan Fox (1966) adalah the involvement of participant and observers in a real problem situation and the desire for resolution and understanding that this involvement engender. Menurut Zuhaerini (1983), model ini digunakan apabila pelajaran dimaksudkan untuk: (a) menerangkan suatu peristiwa yang didalamnya menyangkut orang banyak, dan berdasarkan pertimbangan didaktik lebih baik didramatisasikan daripada diceritakan, karena akan lebih jelas dan dapat dihayati oleh anak; (b) melatih anak-anak agar mereka mampu menyelesaikan masalah-masalah sosialpsikologis; dan (c) melatih anak-anak agar mereka dapat bergaul dan memberi kemungkinan bagi pemahaman terhadap orang lain beserta masalahnya.

Seperti telah dikemukakan di atas, bahwa penggunaan metode ini dalam rangka mencapai tujuan perkuliahan dengan asumsi yang dipegang adalah secara implisit bermain peran mendukung suatu situasi belajar berdasarkan pengalaman dengan menekankan dimensi "di sini dan kini" (here and now) sebagai isi pengajaran. Bermain peran memberikan kemungkinan kepada para siswa untuk mengungkapkan perasaanperasaannya yang tak dapat mereka kenali tanpa bercermin kepada orang lain. selain itu metode ini mengasumsikan bahwa emosi dan ide-ide dapat diangkat ke taraf kesadaran untuk kemudian ditingkatkan melalui proses kelompok. Model mengajar ini mengasumsikan bahwa proses-proses psikologis yang tersembunyi (covert) berupa sikap-sikap nilai-nilai, perasaan-perasaan dan sistem keyakinan dapat diangkat ke taraf kesadaran melalui kombinasi pemeranan secara spontan dan analisisnya.

Untuk dapat mengukur sejauhmana bermain peran memberikan manfaat kepada pemeran dan pengamatnya ditentukan oleh tiga hal, yakni (1) kualitas pemeranan; (2) analisis yang dilakukan melalui diskusi setelah pemeranan; (3) persepsi mahasiswa terhadap peran yang ditampilkan dibandingkan dengan situasi nyata dalam kehidupan. Oleh karena itu perkuliahan dengan metode role playing dilaksanakan menjadi beberapa tahap, yaitu sebagai berikut: (1) tahap memotivasi kelompok; (2) memilih pemeran; (3) menyiapkan pengamat; (4) menyiapkan tahap-tahap permainan peran; (5) pemeranan; (6) diskusi dan evaluasi; (7) pemeranan ulang; (8) diskusi dan evaluasi kedua; (9) membagi pengalaman dan menarik generalisasi.

Hal ini dimulai dengan mengidentifikasi masalah, menetapkan masalah dan mendiskusikan solusinya. Selain itu, para mahasiswa dapat menyelidiki perasaan, sikap, nilai-nilai, dan strategi pemecahan masalah.

\section{Metode Penelitian}

Penelitian ini menggunakan prosedur penelitian tindakan kelas (Classroom action research) yang langkah-langkahnya diadaptasi dari rancangan penelitian tindakan kelas menurut Hopkins dan Elliot (1993:48) dengan tahap-tahap pelaksanaan tindakan kelas secara umum adalah tahap perencanaan, tahap pelaksanaan tindakan, tahap evaluasi, tahap refleksi. Yang terdiri dari 2 siklus, tiap siklus dilaksanakan sesuai dengan perubahan yang ingin dicapai.

Data kualitatif pada penelitian ini adalah data aktivitas perkuliahan mahasiswa diambil melalui lembar observasi aktivitas mahasiswa selama proses perkuliahan berlangsung. Dan data aktivitas pengelolaan dosen mengajar dengan menerapkan perkuliahan menggunakan metode role playing dan dievaluasi pada akhir proses perkuliahan pada setiap siklus.

Aspek yang diamati yaitu prilaku yang relevan dengan kegiatan perkuliahan antara lain :

Interaksi
perkuliahan $\begin{gathered}\text { mahasiswa dalam } \\ \text { meliputi }\end{gathered}$


berdiskusi baik dalam kelompok kecil ataupun klasikal.

2. Keberanian mahasiswa dalam bertanya dan mengemukakan pendapat.

3. Motivasi dan kegairahan dalam mengikuti perkuliahan meliputi kegiatan menyelesaikan tugas mandiri dan aktif memecahkan masalah menggunakan referensi.

Untuk masing-masing indikator di atas, dikategorikan menjadi tiga yaitu aktif, cukup aktif, dan kurang aktif serta diberikan skor secara berturut-turut 3, 2, dan 1. Indikator keberhasilan dalam penelitian ini adalah peningkatan aktivitas pada setiap siklus.

\section{Hasil dan Pembahasan}

Data aktivitas belajar mahasiswa diperoleh dengan mengamati aktivitas mahasiswa selama perkuliahan berlangsung setiap pertemuannya. Data aktivitas ini diambil dengan memperhatikan beberapa aspek yaitu interaksi mahasiswa dalam mengikuti perkuliahan, keberanian mahasiswa dalam mengungkapkan pendapat atau bertanya, motivasi dan kegairahan mahasiswa selama perkuliahan meliputi kegiatan menyelesaikan tugas mandiri dan aktif memecahkan masalah menggunakan referensi.

Berdasarkan hasil pengamatan diperoleh data bahwa aktivitas mahasiswa cenderung mengalami peningkatan pada setiap siklusnya. Sehingga terjadi penurunan jumlah mahasiswa yang tidak aktif dalam perkuliahan. Hal ini menunjukkan bahwa aktivitas mahasiswa semakin baik.

Bahasan pencemaran sebagai ulah manusia secara tidak bijaksana terhadap alam menuntut pemahaman mahasiswa tentang macam - macam pencemaran, dasar fisika kebumian, parameter pencemaran lingkungan, dampak pencemaran, usaha untuk meminimalkan pencemaran serta dampaknya dan persepsi masyarakat terhadap lingkungan sekitar.

Tabel 1. Data deskripsi aktivitas mahasiswa dalam perkuliahan

\begin{tabular}{|c|l|c|r|}
\hline \multirow{2}{*}{ No } & \multicolumn{1}{|c|}{ Indikator } & \multicolumn{2}{c|}{ Siklus } \\
\cline { 3 - 4 } & \multicolumn{1}{|c|}{ I } & II \\
\hline 1 & $\begin{array}{l}\text { Interaksi mahasiswa dalam } \\
\text { perkuliahan }\end{array}$ & 71,5 & 75,3 \\
\hline 2 & $\begin{array}{l}\text { Keberanian mahasiswa } \\
\text { dalam bertanya dan } \\
\text { mengungkapkan pendapat }\end{array}$ & 67,5 & 82 \\
\hline 3 & $\begin{array}{l}\text { Motivasi dan kegairahan } \\
\text { mahasiswa dalam mengikuti } \\
\text { proses perkuliahan }\end{array}$ & 77,1 & 81 \\
\hline & Rata - Rata Aktivitas & 72 & 79,4 \\
\hline & \% Peningkatan & \multicolumn{2}{|c|}{7,4} \\
\hline
\end{tabular}

Metode Role play dalam bahasan diawali dengan membagi mahasiswa menjadi kelompok besar yaitu kelompok mahasiswa pencemaran udara, tanah, air. Dan kemudian dalam kelompok besar dibagi menjadi kelompok masyarakat, pengamat serta penentu kebijakan serta unsur pencemar itu sendiri. Selanjutnya mahasiswa ditugaskan selama satu minggu mencari informasi (searching for information) yang dapat mendukung peran yang akan dibawakan serta dibuat dalam bentuk naskah ilmiah, poster, spanduk dan bentuk lain yang bisa digunakan untuk menguatkan argumen dalam bermain peran.

Tahap tatap muka dilaksanakan dengan posisi tempat duduk $U$-shape dan dosen bertindak sebagai moderator pada saat penampilan. Secara bergantian, tiap kelompok diberi kesempatan untuk memaparkan hasil diskusi kemudian debat terbuka. Penilaian aktivitas kelompok dilakukan pada produk pengemasan informasi pendukung peran yang dimainkan. interaksi mahasiswa dalam perkuliahan, motivasi dan kegairahan mahasiswa dalam perkuliahan serta keberanian mahasiswa bertanya dan mengemukakan pendapat. 
Selain mengobservasi menggunakan lembar aktivitas, metode ask with cards juga digunakan untuk memudahkan penilaian aktivitas individu. Mahasiswa diminta menyiapkan kartu kecil bertuliskan nomor induk (NIM) dalam jumlah tertentu, dan diserahkan pada dosen (moderator) setiap kali melakukan aktivitas yang bersifat konstruktif selama bermain peran. Dan dosen memberikan keterangan pada kartu penilaian sesuai dengan aktivitas yang dilakukan.

Metode Role play biasa digunakan dalam pembelajaran non esak karena sifatnya yang menuntut mahasiswa mampu memainkan peran sosial kemasyarakatan. Bahasan pencemaran merupakan isu yang terus didengungkan akibat perilaku manusia yang tidak bijak dengan alam sekitar sangat lekat dengan aspek sosial. Kebiasaan masyarakat berdasarkan persepsi bahwa dapat memanfaatkan sepuas - puasnya terhadap alam membuat kondisi alam menjadi tidak terperhatikan.

Role play dapat mendorong mahasiswa bersikap kritis dengan dasar argumen ilmiah sesuai pengetahuan yang dikonstruksi dari matakuliah pendukung lain. Mahasiswa dalam menjalankan peran sebagai komponen masyarakat yang manapun, harus mengetahui latar belakang sosial masyarakat yang diperankan sehingga tahu benar dampaknya sehingga dapat menawarkan solusi dan menyampaikan argumen ilmiah berdasar pengetahuan fisika yang dimiliki.

Metode ini mampu mendorong mahasiswa merekonstruksi pengetahuannya tentang sains dasar yang didapat dalam mata kuliah, dan atau informasi yang banyak terdapat di luar perkuliahan.

\section{Simpulan dan Saran}

Berdasarkan hasil refleksi yang dilakukan setiap siklus, penerapan metode Role Playing pada perkuliahan fisika lingkungan sub bahasan pencemaran lingkungan pada mahasiswa pendidikan fisika kerjasama pemda ketapang disimpulkan terdapat peningkatan nilai rata-rata aktivitas siswa dari siklus I sampai dengan siklus II sebesar 7,4\%.

Berdasarkan hasil refleksi pada setiap siklus, penerapan perkuliahan fisika lingkungan bahasan pencemaran menggunakan metode role playing dapat dijadikan sebagai alternatif pendekatan dan metode pembelajaran yang digunakan dalam penyampaian materi. Hal ini dikarenakan mahasiswa dapat mengkonstruksi pemahamannya sendiri berdasarkan mata kuliah sebelumnya dan berpikir kritis terhadap permasalahan yang terjadi disekitarnya dengan argumen yang ilmiah.

\section{Daftar Pustaka}

A.M, Sardiman. 1994. Interaksi dan Motivasi Belajar Mengajar. PT. Raja Grafindo Persada. Jakarta.

Arikunto, Suharsimi. 2001. Dasar-dasar Evaluasi Pendidikan. Bumi Aksara. Jakarta.

James W. Fitzgibbon, Thomas L. Thomson, Design Role-Playing at the School of Architecture, Journal of Architectural Education, Vol. 23, No. 4 (Oct., 1996), pp. 36-39

Departemen Pendidikan Nasional. 2004. Materi Pelatihan Terintegrasi Sains. Direktorat Jenderal Pendidikan Dasar dan Menengah. Jakarta.

Digest,

Eric. 2000. www.knowledgbank.irri.org/IPM/so ccom/SocCom.htm\#. Understanding Farmers Ethnoscie nce_htm

Ertikanto, Chandra. 2003. Diktat Mata kuliah Strategi Belajar Mengajar. Universitas Lampung. Bandar Lampung 
Hamalik. Oemar. 2001. Proses Belajar Mengajar Bumi Aksara. Jakarta.

Memes, Wayan. 2001. Perbaikan Pembelajaran Topik Kalor di SLTP. Jurnal Pendidikan dan pengajaran FKIP Negeri Singaraja. Departemen Pendidikan Nasional RI. hal 17-23.

Mudjiono dan Dimyati. 1994. Belajar dan Pembelajaran. Direktorat Jendral Pendidikan Tinggi. Jakarta.

Sagala, Syaiful. 2005. Konsep dan Makna Pembelajaran. Alfabeta. Bandung.
Slameto. 2003. Belajar dan factor-faktor Yang Mempengaruhinya. Rineka Cipta. Jakarta.

Thoha. Abib. 2001. Teknik Evaluasi Pendidikan. PT. Raja Grafindo Persada. Jakarta.

Wahyudi. 1999. Tinjauan Aspek Budaya Pada Pembelajaran IPA Pentingnya Kurikulum IPA Berbasis Kebudayaan Lokal. Journal of Science Education. Science and Mathematic Education Centre (SMEC) Curtin no 40. 56-72. 